\title{
Factors Influencing Women's Preference to Select a Combined Hormonal Contraceptive Method: A Cross-Sectional Survey in Lithuania
}

\author{
Ramona Čepuliené ${ }^{1}$, Renata Sveikatiené ${ }^{2}$, Kęstutis Gutauskas ${ }^{3}$, Virginija Vanagiené ${ }^{4}$ \\ ${ }^{1}$ JSC "Farmarkesa," ${ }^{2}$ Institute of Physiology and Pharmacology, Medical Academy, Lithuanian University of Health Sciences, \\ ${ }^{3}$ Private Gynecological Practice, ${ }^{4}$ Department of Obstetrics and Gynecology, Medical Academy, \\ Lithuanian University of Health Sciences, Lithuania
}

Key Words: contraception; contraceptives; vaginal ring; skin patch; pill; epidemiological study.

Summary. Background and Objective. Effectiveness and side effects are the main concerns when selecting a contraceptive method. Therefore, the aim of this study was to identify the preference of a combined hormonal contraception method by Lithuanian women, the reasons for selecting one of them and rejecting other two methods, and the factors determining selection or rejection.

Material and Methods. A cross-sectional multicenter survey was performed by the Lithuanian Society of Private Obstetricians and Gynecologists. A total of 4134 women, aged 18-49, who visited their physician due to initiation or reinitiation of hormonal contraception completed self-administered questionnaires identifying the reasons to select one method and reject the two remaining ones. Descriptive and inferential statistics methods were used for data analysis.

Results. The vaginal ring was the most accepted contraception method (55.4\%), followed by the pill (35.6\%). The skin patch was least preferable (9\%). The vaginal ring and the skin patch were mainly selected for the frequency of use $(72.9 \%$ and $51.2 \%$, respectively), convenience $(48.5 \%$ and $71 \%$, respectively), and lower probability of noncompliance (48.7\% and $63.5 \%$, respectively). The main reason for selecting the pill was familiarity with the method (50.7\%). The acceptance of vaginal ring increased with age and was higher among women with higher education.

Conclusions. The most important factors when selecting a contraceptive method among the methods with equal effectiveness and similar safety profile were convenience, frequency of use, and lower probability of noncompliance. Age, education, and employment status were found to be other reasons associated with the choice of contraceptive method.

\section{Introduction}

Contraception use is increasing worldwide, though the popularity of the methods differs per region. The survey reported by the United Nations in 2003 revealed that $48.2 \%$ of European women used contraceptive pills, but in the United States, sterilization was the most popular method (1). The use of contraceptive method also differs across countries. In France, 49\% of women use contraceptive pills, the percentage which is highly comparable to Czech Republic (44\%). At the same time, other European countries including Spain, the Russian Federation, and the Baltic states have one of the lowest rates of contraceptive pill use $(15 \%-18 \%)(2)$.

Despite the fact that the range of contraceptive options and consumer awareness have increased significantly over the last years, still a great number of women do not any protection from unplanned pregnancy. The countries with the lowest use of reliable contraception are at the greatest risk, and different sources present the data that $13.7 \%$ to $28 \%$ of women in the Baltic countries do not use contraception at all $(2,3)$.

Correspondence to R. Čepulienè, V. Daunio 36, 08410 Vilnius, Lithuania. E-mail: ramona.cepuliene@gmail.com
Studies have shown that woman's primary concerns when choosing a contraceptive or not choosing it at all are its effectiveness and side effects (4). Since the introduction of the pill more than 50 years ago, research has focused on providing a high efficacy at the lowest possible dose and optimizing the ease of use. At present, there are new presentations of hormonal contraception with a different intake regimen, frequency of use, and administration route that provide the same level of efficacy, safety, and tolerability. These are oral combined contraceptive pills, vaginal rings, and skin patches (4-7).

Various factors are known to influence a woman's decision when choosing a contraceptive method, but scarce data are available on women's motivations when preferring one method to the other at the time when contraception is started. Therefore, this survey was designed to determine these motivations to be able to further improve contraceptive counseling provided by health care professionals. Moreover, this survey carried out by the Lithuanian Society of Private Obstetricians and Gynecologists (LSPOG) was aimed at gathering information on the factors influencing women's choice while selecting the methods with equal effectiveness and similar safety profile. 


\section{Material and Methods}

Part of the data obtained during the LSPOG survey, which aimed to determine the acceptance of combined hormonal contraceptive methods in women seeking contraceptive counseling, served as the basis for this study. A cross-sectional multicenter survey was carried out between October 1, 2007, and January 1, 2008. All consecutive women aged 18-49 years who consulted their gynecologist in outpatient departments, family clinics, or private gynecological clinics during the mentioned period for the initiation or reinitiation of hormonal contraception (after a nonuse period of hormonal contraception not shorter than 6 months) and who gave written informed consent to answer a questionnaire were included into the study. Women who did not meet eligibility criteria or had health conditions limiting the use of combined hormonal contraception were excluded from the survey. Women completed a self-administered questionnaire regarding the reasons for selecting a certain method of contraception and for rejecting of other two methods.

In order to avoid the probability of inconclusiveness, women were interviewed in health care institutions across all Lithuania, located in the way to represent the total population of the women of reproductive age in the country. The survey was conducted under routine clinical practice conditions.

Contraception counseling included exhaustive information including effectiveness of the methods, modes of their action and use, possible risks and benefits, and fit for individual needs. In order to back up verbal information on contraception methods, all investigators received a leaflet on the combined hormonal contraceptive methods (Table 1).

The data, which were considered to have a possibility to influence the choice of the contraceptive method, were collected, including but not limited to age, education, gynecological history, marital status, employment, and previously used contraception methods.

Statistical analysis was performed using the SPSS (Statistical Package for Social Sciences v10.0) software. Descriptive analysis was performed as well. Data were expressed as absolute numbers and percentages, and mean and standard deviations (SD). Comparisons between the groups were made by using ANOVA and the chi-square $\left(\chi^{2}\right)$ test, and a $P$ value of $<0.05$ was considered as statistically significant.

\section{Results}

A total of 4134 women aged 18-49 years answered the questionnaire, with the majority of respondents (71.9\% of all study population) being 20-34 years old. The mean age of the women was 27.88 years (SD, 6.84). The mean numbers of previous pregnancies and deliveries were 2.28 (SD, 1.29) and 1.59 (SD, 0.65), respectively.

With regard to education level, most women were educated: $36.5 \%$ of the survey participants had

Table 1. Details of the Patient Counseling Tool Used During the Survey

\begin{tabular}{|c|c|c|c|c|c|c|}
\hline $\begin{array}{c}\text { Combined } \\
\text { Contraceptive } \\
\text { Method } \\
\end{array}$ & $\begin{array}{l}\text { Mechanism } \\
\text { of Action }\end{array}$ & Efficacy & $\begin{array}{c}\text { Contraceptive } \\
\text { Regimen }\end{array}$ & $\begin{array}{c}\text { Route of } \\
\text { Administration }\end{array}$ & Description & A Woman Should Know \\
\hline Vaginal ring & $\begin{array}{l}\text { Ovulation } \\
\text { inhibition }\end{array}$ & $>99 \%$ & $\begin{array}{l}1 \text { ring for con- } \\
\text { tinuation of } 3 \\
\text { weeks, } 1 \text { week } \\
\text { free of ring }\end{array}$ & Vaginal & $\begin{array}{l}\text { Frequency of use: once a } \\
\text { month, discreet. } \\
\text { Route of administration: no } \\
\text { interference with vomiting } \\
\text { or diarrhea, avoids first liver } \\
\text { passage, constant and low } \\
\text { hormone levels, efficacy not } \\
\text { decreased by oral antibiotics. }\end{array}$ & $\begin{array}{l}\text { Better cycle control, low } \\
\text { possibility of inadvertent } \\
\text { omission, low probabil- } \\
\text { ity for a ring to fall out } \\
(<1 \%) \text {, convenience of } \\
\text { use, other benefits at- } \\
\text { tributed to all combined } \\
\text { methods. }\end{array}$ \\
\hline Skin patch & & & $\begin{array}{l}1 \text { patch/week } \\
\text { for } 3 \text { subse- } \\
\text { quent weeks, } \\
1 \text { week free of } \\
\text { patch }\end{array}$ & Transdermal & $\begin{array}{l}\text { Frequency of use: once a } \\
\text { week; } \\
\text { Route of administration: no } \\
\text { interference with vomiting } \\
\text { or diarrhea, avoids first liver } \\
\text { passage. }\end{array}$ & $\begin{array}{l}\text { Easy to stick on, low } \\
\text { possibility of inadvertent } \\
\text { omission, higher prob- } \\
\text { ability of mastodynia, is } \\
\text { not suitable for women } \\
\text { weighing more than } \\
90 \mathrm{~kg} \text {, other benefits at- } \\
\text { tributed to all combined } \\
\text { methods. }\end{array}$ \\
\hline $\begin{array}{l}\text { Contraceptive } \\
\text { pill }\end{array}$ & & & $\begin{array}{l}1 \text { pill for } 21 / 22 \\
\text { days followed } \\
\text { by } 7 / 6 \text { days } \\
\text { without a pill } \\
\text { or } 1 \text { pill/day } \\
\text { for } 28 \text { days }\end{array}$ & Oral & $\begin{array}{l}\text { Frequency of use: once a day } \\
\text { Familiar route of administra- } \\
\text { tion, hormone level changes } \\
\text { in a course of a day. }\end{array}$ & $\begin{array}{l}\text { Method with the largest } \\
\text { experience, daily depend- } \\
\text { ence, proven beneficial } \\
\text { contraceptive and non- } \\
\text { contraceptive benefits. }\end{array}$ \\
\hline
\end{tabular}

Three methods of combined hormonal contraception are presented in this table. All 3 methods provide a fixed dose of estrogen and progestogen. These 3 methods are not significantly different regarding efficacy, safety, and tolerability. The main difference is the frequency of use and route of administration, which can make a difference in terms of convenience. 
a university degree, $34.8 \%$ had secondary education, and $27.2 \%$ had specialized secondary education. Only $1.2 \%$ of respondents had primary education, and $0.3 \%$ of women did not provide any information concerning their education. With regard to employment status, $64.1 \%$ of women were employed, $21 \%$ were students, $7 \%$ worked at home, only $7 \%$ were unemployed, and $0.9 \%$ of respondents did not provide any information regarding their employment status. Most women had a stable partner (80.1\%).

Condoms (36.1\%) and coitus interruptus (21.3\%) were the most popular contraceptive methods used by study participants; $20.1 \%$ of women did not use any method of contraception.

Table 2 summarizes demographic and gynecological data of the study participants.

After consultation, women filled in the study questionnaire and reported which hormonal contraceptive method would be most preferable by them. The vaginal ring $(55.4 \%)$, followed by the pill (35.6\%), was a contraceptive method preferred by the majority of women. The least popular method was the contraceptive patch indicated only by $9 \%$ of the survey participants.

The vaginal ring was mainly preferred because of its monthly use $(72.9 \%)$, convenience $(48.5 \%)$, and lower possibility of noncompliance $(48.7 \%)$, naming also other reasons as discreetness and low and stabile hormone dose. The contraceptive ring was mainly rejected due to the refusal of vaginal insertion $(39.8 \%)$, fear of feeling a foreign body in the vagina $(36.5 \%)$, and fear that the ring will fall out $(34.9 \%)$. The above reasons were more frequently reported among women who preferred the skin patch than among those who preferred the contraceptive pill.

The contraceptive pill was mainly selected due to a familiarity of the method $(50.7 \%)$, convenience $(44.3 \%)$, and proven efficacy of the method $(40.6 \%)$. The fifth most frequently named reason to select a pill was that the method was used by one of female friends (21.3\%). Daily intake $(62.5 \%)$ and possibility of noncompliance $(61.9 \%)$ were the most frequently named reasons for rejecting the contraceptive pill.

The contraceptive patch was mainly selected because of convenience $(71 \%)$, lower possibility of noncompliance $(63.5 \%)$, and frequency of use once a week $(51.2 \%)$. The main reasons for rejecting the skin patch were the possibility of detachment and/or skin irritation $(52.5 \%)$, perception that the method is unreliable (36\%), and lack of discreetness $(24.6 \%)$.

The reasons for selecting or rejecting a certain contraceptive method are listed in Table 3.

Table 4 shows the associations between women's characteristics and the choice of contraceptive hormonal method. Among the women with primary and secondary education, the contraceptive pill was the most preferable method of contraception $(2.2 \%$ and $42.9 \%$, respectively; $P<0.001)$. Women with
Table 2. Demographic and Gynecological Data of Participants

\begin{tabular}{lc}
\hline \multicolumn{1}{c}{ Variable } & No. $(\%)$ \\
\hline Age, years & \\
$18-19$ & $380(9.2)$ \\
$20-24$ & $1184(28.6)$ \\
$25-29$ & $1000(24.2)$ \\
$30-34$ & $790(19.1)$ \\
$35-39$ & $505(12.2)$ \\
$40-44$ & $209(5.1)$ \\
$45-49$ & $53(1.3)$ \\
No information available & $13(0.3)$ \\
\hline Steady partner & $3312(80.1)$ \\
Yes & $465(11.2)$ \\
No & $357(8.6)$ \\
No information available & \\
\hline Current contraception method* & $1494(36.1)$ \\
Condom & $882(21.3)$ \\
Coitus interruptus & $829(20.1)$ \\
Does not use any contraception & $285(6.9)$ \\
Unmedicated intrauterine device & $821(19.9)$ \\
Other & $110(2.7)$ \\
No information available & \\
\hline
\end{tabular}

*Some respondents used several contraception methods at the same time.

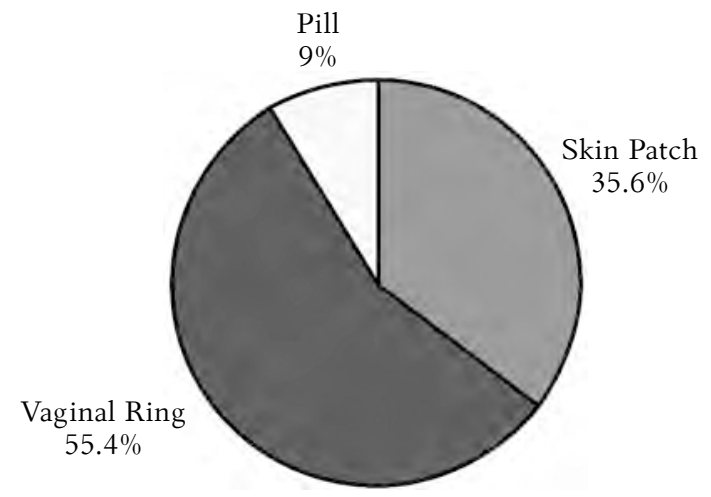

Fig. 1. The preference of contraceptive methods during consultation

higher university preferred the contraceptive ring significantly more frequently than other method of contraception $(41.6 \%)$. A significantly greater percentage of employed women preferred the contraceptive ring $(69.6 \%)$ compared with the contraceptive patch $(61.4 \%)$ and the contraceptive pill $(57.9 \%)$. Students and unemployed women selected the contraceptive pill more frequently $(26.5 \%$ and $8.7 \%$, respectively; $P<0.001)$ than the contraceptive ring $(17.2 \%$ and $5.9 \%$, respectively; $P<0.001)$ or the contraceptive patch $(25.1 \%$ and $7.8 \% ; P=0.004)$. A significantly higher percentage of women who reported that an unmedicated intrauterine device was the current contraception method used selected the contraceptive ring $(8.8 \%)$ than the contraceptive pill $(6.0 \%)$ or the contraceptive patch $(5.8 \%)$ more frequently $(P=0.043)$.

The associations between the choice of hormonal contraception method and women's age by age groups are shown in Fig. 2. The use of the skin 
Table 3. Reasons for Selecting or Rejecting a Certain Contraceptive Method

\begin{tabular}{|c|c|c|}
\hline Reason & $\begin{array}{l}\text { No. of Women } \\
\text { Answered }\end{array}$ & $\begin{array}{c}\% \text { (of Total No. } \\
\text { of Women) }\end{array}$ \\
\hline \multicolumn{3}{|l|}{ Reasons for selecting the contraceptive ring } \\
\hline Monthly use & 1668 & 72.9 \\
\hline Lower possibility of noncompliance & 1115 & 48.7 \\
\hline Convenience & 1110 & 48.5 \\
\hline Low and stabile hormone dose & 677 & 29.6 \\
\hline Discreetness & 497 & 21.7 \\
\hline No interference with vomiting and/or diarrhea & 129 & 5.6 \\
\hline Oral antibiotics do not affect efficacy & 129 & 5.6 \\
\hline Other reasons & 113 & 4.9 \\
\hline No answer & 5 & 0.2 \\
\hline \multicolumn{3}{|c|}{ Reasons for rejecting the contraceptive ring (answers of women choosing pill or patch) } \\
\hline Refusal of vaginal insertion & 735 & 39.8 \\
\hline Fear of feeling a foreign body in vagina & 637 & 36.5 \\
\hline Fear that the ring will fall out & 644 & 34.9 \\
\hline Suspicion of discomfort & 613 & 33.2 \\
\hline Distrust of efficacy/looks unreliable & 438 & 23.7 \\
\hline Partner's refusal & 110 & 6.0 \\
\hline Acquaintances' contrary opinion & 66 & 3.6 \\
\hline Other reasons & 144 & 7.8 \\
\hline No answer & 29 & 1.6 \\
\hline \multicolumn{3}{|l|}{ Reasons for selecting the contraceptive pill } \\
\hline Familiarity of the method & 747 & 50.7 \\
\hline Convenience & 652 & 44.3 \\
\hline Proven efficacy of the method & 597 & 40.6 \\
\hline Ease of use & 547 & 34.2 \\
\hline Used by one of female friends & 314 & 21.3 \\
\hline Daily use & 245 & 16.6 \\
\hline Acceptable for my partner & 88 & 6.0 \\
\hline Other reasons & 134 & 9.1 \\
\hline No answer & 5 & 0.3 \\
\hline \multicolumn{3}{|l|}{ Reasons for rejecting the contraceptive pill } \\
\hline Risk of noncompliance & 1688 & 63.4 \\
\hline Daily intake & 1656 & 62.3 \\
\hline There are other more convenient methods & 795 & 29.9 \\
\hline Old-fashioned method & 484 & 18.2 \\
\hline Interference with vomiting and/or diarrhea & 203 & 7.6 \\
\hline Acquaintances' contrary opinion & 181 & 6.8 \\
\hline Partner's refusal & 31 & 1.2 \\
\hline Other reasons & 125 & 4.7 \\
\hline No answer & 60 & 2.3 \\
\hline \multicolumn{3}{|l|}{ Reasons for selecting the contraceptive patch } \\
\hline Convenience & 265 & 71 \\
\hline Lower possibility of noncompliance & 237 & 63.5 \\
\hline Weekly use & 191 & 51.2 \\
\hline Easy handling & 119 & 31.9 \\
\hline Visibility & 71 & 19.0 \\
\hline No interference with vomiting and/or diarrhea & 31 & 8.3 \\
\hline Oral antibiotics do not affect efficacy & 20 & 5.4 \\
\hline Other reasons & 18 & 4.8 \\
\hline No answer & 1 & 0.3 \\
\hline \multicolumn{3}{|l|}{ Reasons for rejecting the contraceptive patch } \\
\hline Fear of detachment/skin irritation & 1892 & 50.3 \\
\hline Distrust of efficacy/looks unreliable & 1450 & 38.6 \\
\hline Lack of discreetness & 927 & 24.6 \\
\hline There are other more convenient methods & 835 & 22.2 \\
\hline Acquaintances' contrary opinion & 512 & 13.6 \\
\hline Too new method & 245 & 6.5 \\
\hline Partner's refusal & 139 & 3.7 \\
\hline Other reasons & 235 & 6.2 \\
\hline No answer & 92 & 2.4 \\
\hline
\end{tabular}

patch decreased with decreasing age, while the contraceptive pill was most preferable by the youngest and oldest women's groups. Women aged 25 to 44 years preferred the vaginal ring.

\section{Discussion}

A study by Tschudin et al. reported that according to the opinion of gynecologists, efficiency $(100 \%)$, reversibility $(83 \%)$, side effects $(85 \%)$, and convenience $(79 \%)$ were the most important factors affecting a contraceptive choice among women (8). 
Table 4. Women's Sociodemographic Characteristics According to the Combined Contraceptive Method Chosen

\begin{tabular}{|c|c|c|c|c|}
\hline Characteristic & Contraceptive Pill & Contraceptive Ring & Contraceptive Patch & $P$ \\
\hline Age, mean (SD), years & $26.82(6.99)$ & $28.7(6.64)$ & $27.02(6.78)$ & $<0.001$ \\
\hline $\begin{array}{c}\text { Age, } \mathrm{n}(\%) \\
18-19 \text { years } \\
20-24 \\
25-29 \\
30-34 \\
25-39 \\
40-44 \\
45-49 \\
\text { Total } \\
\end{array}$ & $\begin{array}{c}201(13.7) \\
486(33.1) \\
313(21.3) \\
232(15.8) \\
152(10.3) \\
62(4.2) \\
24(1.6) \\
1470(100)\end{array}$ & $\begin{array}{c}137(6.0) \\
577(25.3) \\
602(26.4) \\
490(21.5) \\
315(13.8) \\
131(5.8) \\
26(1.2) \\
2278(100)\end{array}$ & $\begin{array}{c}42(11.3) \\
121(32.4) \\
85(22.8) \\
68(18.2) \\
38(10.2) \\
16(4.3) \\
3(0.8) \\
373(100)\end{array}$ & $\begin{array}{l}P \text { in all groups } \\
<0.001\end{array}$ \\
\hline $\begin{array}{l}\text { Stable partner, n (\%) } \\
\text { Yes } \\
\text { No } \\
\text { Total } \\
\end{array}$ & $\begin{array}{c}1210(87.7) \\
170(12.3) \\
1380(100) \\
\end{array}$ & $\begin{array}{l}1805(87.7) \\
253(12.3) \\
2058(100)\end{array}$ & $\begin{array}{c}297(87.6) \\
42(12.4) \\
339(100)\end{array}$ & 0.999 \\
\hline $\begin{array}{l}\text { Education, } \mathrm{n}(\%) \\
\text { Primary } \\
\text { Secondary } \\
\text { Specialized secondary } \\
\text { University } \\
\text { Total } \\
\end{array}$ & $\begin{array}{c}32(2.2) \\
630(42.9) \\
392(26.7) \\
415(28.3) \\
1469(100) \\
\end{array}$ & $\begin{array}{l}14(0.6) \\
672(29.4) \\
647(28.4) \\
949(41.6) \\
2282(100) \\
\end{array}$ & $\begin{array}{c}5(1.3) \\
138(37.0) \\
85(22.8) \\
145(38.9) \\
33(100) \\
\end{array}$ & $\begin{array}{l}<0.001 \\
<0.001 \\
0.068 \\
0.001\end{array}$ \\
\hline $\begin{array}{l}\text { Employment status, n (\%) } \\
\text { Working } \\
\text { Working at home } \\
\text { Student } \\
\text { Unemployed } \\
\text { Total } \\
\end{array}$ & $\begin{array}{c}842(57.9) \\
101(6.9) \\
385(26.5) \\
127(8.7) \\
1455(100) \\
\end{array}$ & $\begin{array}{c}1581(69.6) \\
167(7.3) \\
391(17.2) \\
134(5.9) \\
2273(100)\end{array}$ & $\begin{array}{c}227(61.4) \\
21(5.7) \\
93(25.1) \\
29(7.8) \\
370(100) \\
\end{array}$ & $\begin{array}{l}<0.001 \\
0.497 \\
<0.001 \\
0.004\end{array}$ \\
\hline $\begin{array}{l}\text { Current contraceptive method*, n (\%) } \\
\text { Condom } \\
\text { Coitus interruptus } \\
\text { Unmedicated intrauterine device } \\
\text { No contraception } \\
\text { Other } \\
\text { Total }\end{array}$ & $\begin{array}{c}556(38.7) \\
330(23.0) \\
86(6.0) \\
306(21.3) \\
254(17.7) \\
1437(106.6)\end{array}$ & $\begin{array}{c}798(35.8) \\
474(21.3) \\
178(8.8) \\
434(19.5) \\
507(22.8) \\
2227(107.4)\end{array}$ & $\begin{array}{l}140(38.9) \\
78(21.7) \\
21(5.8) \\
89(24.7) \\
60(16.7) \\
360(107.8) \\
\end{array}$ & $\begin{array}{l}0.167 \\
0.483 \\
0.043 \\
0.054 \\
<0.001\end{array}$ \\
\hline
\end{tabular}

*Some respondents used several contraception methods.

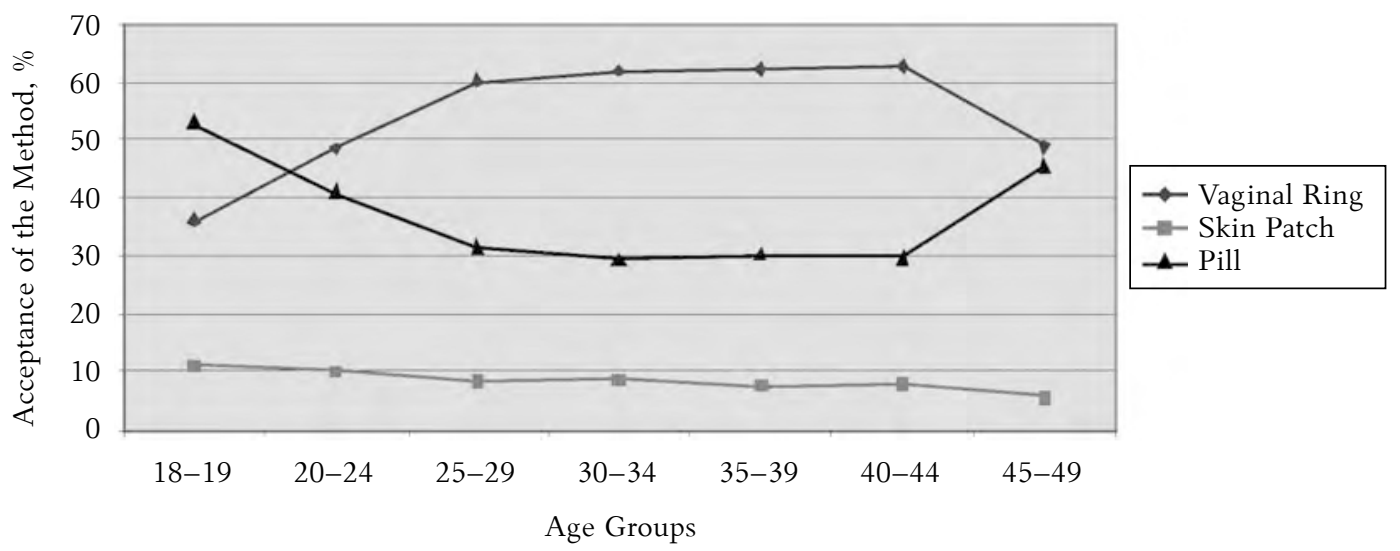

Fig. 2. Associations between women's age and preference of combined hormonal contraception

The aim of this study was to find out what reasons determined our women's preference.

The combined contraceptive pill is the most popular method of contraception in many countries. It meets the requirements for contraception listed above. According to the data of one large-scale European survey, there are more than 22 million pill users in $5 \mathrm{EU}$ countries (France, the United Kingdom, Italy, Spain, and Germany) (9). Although the use of hormonal contraception in Lithuania in gen- eral is rather low and reaches $16 \%(2)$, the pill is the most popular method among the methods of hormonal contraception (10).

Based on these data, the hypothesis before starting the survey was that women would select the combined pill most frequently, and the two remaining methods - contraceptive ring and the skin patch - would be less popular. In order to minimize the effect that biased information may have an influence on the selection of a contraceptive method, 
uniform written information to be used during a consultation was provided to all consulting gynecologists. However, the provision of complete information concerning the alternatives resulted in different choices: the contraceptive ring used once a month showed the highest preference among the survey participants. There are many scientific articles analyzing the factors affecting the choice of contraceptives. The factors such as religious beliefs and sociodemographic characteristics, including education level, race, insurance status, and sexual history, were proven as having an influence on the choice of contraceptives (11). However, the listed factors are definitely not the only ones influencing the choice. Choosing the right contraceptive involves selecting not only the most efficacious, but also the most practical, acceptable, and tolerable method to that individual. Personal lifestyles, cultural and health beliefs have to form the foundation for discussion to ensure that women use a contraceptive method that fits them best (12). The importance of personal lifestyle and how a contraception method fits women's needs can be also identified from the results of the performed survey. One of the main reasons for discontinuing pill use was daily intake mentioned by $28 \%$ of European women (2). According to the reasons reported for the suitability of each method in the presented survey, it can be concluded the pill was mainly rejected because of the possibility of inadvertent omission and the need of daily intake, and the new methods were preferred for the reasons of convenience, lower probability of inadvertent omission, and other than daily frequency of use.

Combined hormonal contraception methods are highly effective when used correctly, and a failure is largely related to incorrect or inconsistent use of the method. Incorrect use is highly prevalent among pill users: up to $47 \%$ of pill users reported missing at least 1 pill per cycle within a 2 -month period and $22 \%$ reported missing 2 or more pills per cycle (13). In a Portuguese study, gynecologists reported even the smaller percentages of compliance with oral methods. They believed that only $2 \%$ of women taking the pill were $100 \%$ compliant (14). However, it is still unclear if nondaily contraceptive methods could improve compliance. Data from clinical studies comparing the use of pill, vaginal ring, or contraceptive patch did not demonstrate a significant improvement in compliance $(15,16)$. Gynecologists believed that $48 \%$ of women using the patch and $75 \%$ of those using the ring were compliant (14). Similar expectations were confirmed by our study participants: one of the reasons for selecting the methods of nondaily use (both the vaginal ring and the contraceptive patch) was the statement of respondents that the nondaily use of contraception may decrease the risk of noncompliance.
In a similar Spanish study, which analyzed the factors affecting the choice of hormonal contraception, the preference of contraceptive patch increased with age (17). The findings of one U.S. study indicated a good compliance and tolerability with the contraceptive patch among adolescents (18). In our study, the preference of the contraceptive patch was more in line with that of the last abovementioned study, being greater in the younger population and decreasing with age, although the percentages of women using this method in all age groups were lowest as compared with other methods.

Consulting a woman, gynecologists apply medical eligibility criteria for a certain contraceptive method and take into consideration other patient-specific factors. Except applying the mentioned criteria, medical professionals can influence the choice by other means. Visiting a medical professional is often stress for a woman, and besides this, many women do not understand the traditional methods of providing oral information due to the lack of knowledge, poor recall, and low literacy (12). The use of explanatory means other than oral (as an unified explanatory tool used in this study) can increase women's ability to understand information provided and make a more informed choice of their contraceptive method and promote the use of contraception.

The choice of methods refers to both the number of contraceptive methods offered on a reliable basis and their intrinsic variability (19). By providing an appropriate choice of contraceptive methods, the greatest number of clients will be able to use a method that is suited to their social and medical situation. In spite of the theoretical availability of many options, practitioners usually restrict themselves by contraceptive costs (rather than cost-effectiveness), leading to the exclusion of some newer regimens that might otherwise suit women who have experienced side effects or problems with older-generation regimens (20).

As stated by Bertrand et al., sometimes outdated and anachronistic contraindications may be overzealously applied by medical professionals (21), and such eligibility barriers may reduce the access of some women to particular methods. Data from some studies indicate that many providers have selfimposed age and parity limits on the provision of particular methods (22).

There is a hypothesis that doctor's gender could also have an impact on contraception counseling (8, 14). Male and female gynecologists inform equally frequently about various methods and reproductive health aspects such as risks, the advantages and disadvantages of the methods, and side effects. Male physicians speak more often about the efficiency and benefits of the methods, while their female colleagues emphasize sexually transmitted infections and emergency contraception as well as naturalness 
and cost of the method (8). Although it could be an interesting point of view, it was not possible to determine a possible impact of gynecologists' gender on contraception counseling and further contraceptive choice in this survey as there were 98 female and only 2 male gynecologists participating in this survey.

The results of the present survey are also useful in defining the profile of the Lithuanian women who want to use combined hormonal contraception methods. These methods are mostly preferred by employed, better-educated women who are aged 20 to 34 years and live with a stable partner. These findings are consistent with those of studies carried in other European countries (9). Finally, it has to be noted that complete information from a medical professional, use of more information sources not only oral (for example, written or video materials) for explanation, and factors associated with convenience, frequency of use, and lower probability of inadvertent omission were much more important factors than women's profile. Convenience, frequency of use, and lower probability of noncompli-

\section{References}

1. Population Division, Department of Economic and Social Affairs, United Nations. World contraception use 2003. Available from: URL: http://www.un.org/esa/population/ publications/contraceptive2003/About WCU2003

2. Cibula D. Women's contraceptive practices and sexual behaviour in Europe. Eur J Contracept Reprod Healt Care 2008;13(4):362-75.

3. Vanagienè V, Čepulienè R, Grauslienè E. Kontracepcijos vartojimo Lietuvoje ypatybès. Kas pasikeitè per 10 metu?? (Peculiarities of contraception use in Lithuania. What has changed during the 10 years period?) Lietuvos bendrosios praktikos gydytojas (Kaunas) 2007;11(10):661-6.

4. Foran TM. New contraceptive choices across reproductive life. Med J Aust 2003;178:616-20.

5. Herndon EJ, Zieman M. New contraceptive options. Am Fam Physician 2004;69(4):853-60.

6. Plourd DM, Rayburn WF. New contraceptive methods. J Reprod Med 2003;48:665-71.

7. Burton FG, Skiens WE, Dunkan GW. Low level progestogen-releasing vaginal contraceptive devices. Contraception 1979;19:507-16.

8. Tschudin S, Alder J, Bitzer J, Merki GS. Contraceptive councelling by gynecologists - which issues are discussed and does gender play a role? J Psychosom Obstet Gynaecol 2007;28(1):13-9.

9. Skouby SO. Contraceptive use and behaviour in the 21st century: a comprehensive study across five European countries. Eur J Contracept Reprod Health Care 2004;9:57-68.

10. Vanagienė V, Čepulienè R. Sudètinès hormoninès kontracepcijos priemonès vartojimo režimo pažeidimų reikšmė emocinei moteru būklei ir tolesniam elgesiui bei kontracepcijos priemoniu pasirinkimui. (Impact of non-compliance with combined hormonal contraception on woman's emotional status, further sexual behaviour and future contraceptive choice.) Akušerija ir ginekologija (Kaunas) 2010;13(2): 147-57.

11. Krings K, Mattesson J, Allsworth E, Peipert J. Contraceptive choice: how do oral contraceptive users differ from condom users and women who use no contraception? Am J Obstet Gynecol 2008;198(5):46-7. ance were the main reason influencing the women's choice. Medical professionals should inform patients on more than one contraception alternative. This may result in a choice of method different that was expected by a health care professional, but better corresponding to woman's needs. This is also confirmed by the findings of the Portuguese gynecologists' survey in which $90 \%$ of gynecologists considered that deciding on contraceptive methods was a process wherein the woman had her say (14).

\section{Conclusions}

The women preferring the contraceptive ring were older, had higher education, and were professionally active more frequently. The factors associated with convenience, frequency of use, and lower probability of inadvertent omission were most important when selecting a certain combined contraception method.

\section{Statement of Conflict of Interest}

The authors state no conflict of interest.

12. Bajos N, Leridon H, Goulard H, Oustry P, Job-Spira N; COCON Group. Contraception: from accessibility to efficiency. Hum Reprod 2003;18(5):994-9.

13. Rosenberg M, Waugh MS. Causes and consequences of oral contraceptive non-compliance. Am J Obstet Gynecol 1999; 180:S276-9.

14. Gardner M. Cicred's seminar. Service factors affecting access and choice of contraceptive services in Myanmar. Available from: URL: http://www.cicred.org/Eng/Seminars/ Details/Seminars/Bangkok2002/33BangkokTheinThein HtayGardner.pdf. Accessed September 15, 2010.

15. Milsom I, Lete I, Bjertnaes A, Rokstad K, Lindh I, Gruber CJ, et al. Effects on cycle control and bodyweight of the combined contraceptive ring, NuvaRing, versus an oral contraceptive containing $30 \mathrm{mkg} \mathrm{EE}$ and $3 \mathrm{mg}$ drosperinon. Hum Reprod 2006;21:2304-11.

16. Archer DF, Cullins V, Creasy GW, Fisher AC. The impact of improved compliance with a weekly contraceptive transdermal system (Ortho Evra) on contraceptive efficacy. Contraception 2004;69:189-95.

17. Lete I, Doval JL, Perez-Campo E, Sanchez-Borrego R, Correa $M$, Viuda E, et al. Factors affecting women's selection of a combined hormonal contraceptive method: the TEAM-06 Spain cross-sectional study. Contraception 2007;76:77-83.

18. Harel Z, Riggs S, Vaz R, Flanagan P, Dunn K, Harel D. Adolescents' experience with the combined estrogen and progestin transdermal contraceptive method Orto Evra. J Pediatr Adolesc Gynecol 2005;18:85-90.

19. Bruce J. Fundamental elements of the quality of care: a simple framework. Stud Fam Plann 1990;21(2):61-91.

20. Panay N, Bellogne C. Availability of contraceptive choice. Trends Urol Gynaecol Sex Health 2010;15(3):4-5.

21. Bertrand JT, Hardee K, Magnani RJ, Angle MA. Access, quality of care and medical barriers in family planning programs. Int Famy Plann Perspect 1995;21(2):64-74.

22. Bombas T, Costa AR, Palma F, Vicente L, Sa JL, Nogueira AM, et al. Knowledge-attitude-practice survey among Portuguese gynaecologists regarding combined hormonal contraceptives methods. Eur J Contracept Reprod Health Care 2012;17(2):128-34. 